\title{
THE POTENTIAL TO RECONSTRUCT MANASI RIVER STREAMFLOW IN THE NORTHERN TIEN SHAN MOUNTAINS (NW CHINA)
}

\author{
YUJIANG YUAN* \\ Institute of Desert Meteorology \\ CMA, Urumqi 830002, China \\ Swiss Federal Research Institute WSL \\ 8903 Birmensdorf, Switzerland \\ XUEMEI SHAO \\ Institute of Geographical Sciences and Resources \\ CAS, Beijing 100101, China \\ WENSHOU WEI and SHULONG YU \\ Institute of Desert Meteorology \\ CMA, Urumqi 830002, China \\ YUAN GONG \\ Hydrological and Water Resources Bureau of Xinjiang \\ Urumqi 830000, China
}

and

VALERIE TROUET

Swiss Federal Research Institute WSL

8903 Birmensdorf, Switzerland

\begin{abstract}
We present a tree-ring based reconstruction of water-year (October-September) streamflow for the Manasi River in the northern Tien Shan mountains in northwestern China. We developed eight Tien Shan spruce (Picea schrenkiana Fisch. et Mey.) chronologies for this purpose, which showed a common climatic signal. The hydroclimatic forcing driving tree growth variability affected streamflow with a three- to four-year lag. The model used to estimate streamflow is based on the average of three chronologies and reflects the autoregressive structure of the streamflow time series. The model explains $51 \%$ of variance in the instrumental data and allowed us to reconstruct streamflow for the period 1629-2000. This preliminary reconstruction could serve as a basis for providing a longer context for evaluating the recent (1995-2000) increasing trends in Manasi River streamflow and enables the detection of sustained periods of drought and flood, which are particularly challenging for managing water systems. Several of the reconstructed extended dry (wet) periods of the Manasi River correspond to reconstructed periods of drought (flood) in Central Asia in general and in other Tien Shan mountain locations in particular, suggesting that the analysis of Tien Shan spruce could contribute significantly to the development of regionally explicit streamflow reconstructions.
\end{abstract}

*Corresponding author: Yuanyuj5502@sina.com 
Keywords: tree-ring chronology, streamflow reconstruction, Picea schrenkiana, Tien Shan Mountains, Manasi River, northwestern China.

\section{INTRODUCTION}

The Tien Shan in northwestern China has experienced dramatic climatic and hydrologic changes since the beginning of the $20^{\text {th }}$ Century in general and in the last few decades in particular. Human-induced global $\mathrm{CO}_{2}$ enrichment has led to unambiguous warming over central Asia (Hansen 1988; Esper et al. 2002; Hu et al. 2003; Tian et al. 2006). The northern Tien Shan mountain range in particular has been characterized by increasing temperatures over the second half of the $20^{\text {th }}$ Century (Aizen et al. 1997; Esper et al. 2003; Su et al. 2005; Ye et al. 2005; Esper et al. 2007). Glacier retreat and glacier melt in the Tien Shan mountains were enhanced by temperature increases (Xie et al. 2004; Su et al. 2005; Ye et al. 2005).

Rising temperatures since the 1980s were accompanied by an increasing trend in precipitation (Aizen et al. 1997, 2001; Su et al. 2005; Ye et al. 2005; Shi et al. 2007), leading to an increase in flood frequency and flooded area (Jiang et al. 2005; Mao et al. 2005). Although social factors (e.g. land use change) have been proposed as drivers of flood disaster increases (Jiang et al. 2002), recent floodings have generally been attributed to natural factors and global warming. Like many developing countries, China is strongly affected by natural hazards and extreme climatic events, floods in particular. Flood disasters threaten agricultural development, property, and human lives, and the associated economic losses hinder regional economic development (Jiang et al. 2005).

Annual streamflow of rivers in the Tien Shan area has generally increased since the 1980s, because of increased precipitation and enhanced glacier melt (Mao et al. 2004; Chen et al. 2005; Ye et al. 2005; Shi et al. 2007). The response of streamflow to climate variability, however, is regionally variable ( $\mathrm{He}$ et al. 2003; Shi et al. 2007). Gong et al. (2003) found an increase in streamflow in rivers with runoff-producing areas at high elevations (e.g. northern Tien Shan mountain range), but a decreasing streamflow in rivers at lower elevations. Enhanced annual streamflow has been detected in glacier-fed rivers, where the proportion of glacier melt water has increased over recent decades (Ye et al. 1999; Xie et al. 2004). Despite the explicit interannual trend in glacier-fed river streamflow, the persistence of seasonal streamflow distribution is unreliable (Xie et al. 2004). Streamflow of many rivers in the Xinjiang autonomous province has increased in Spring since the 1980s, coinciding with intensive snowmelt, but decreased in Summer (Ye et al. 1999). The poor reliability of surface water resources is an impediment for their utilization and sustainable management. Climate modeling efforts (Gao et al. 2001) predict a further increase in precipitation and annual streamflow under potentially steeper $\mathrm{CO}_{2}$ enrichment conditions in the near future.

The observed increasing trends in temperature, precipitation, and streamflow since the 1980s indicate that a climate shift from warm-dry to warm-wet has occurred in northwestern China (Shi et al. 2007). The temporal (decadal or centennial scale) and spatial extent of this climate shift, however, is subject to important uncertainties. An extensive hydrometeorological network has been established in the Tien Shan area, but reliable instrumental data are only available from the 1950s onwards (Aizen et al. 1997). Quantitative information about long-term hydroclimatic variability therefore needs to be recovered from proxy records to view recent climatic change in a longer-term perspective. Tree-ring data are particularly valuable in this context, because of their strong climatological sensitivity, their extensive spatial distribution, and the possibility for precise, absolute dating (Fritts 1976).

Tree-ring analysis has been successfully applied to reconstruct drought variability in central Asia (Pederson et al. 2001; Wang et al. 2005; Davi et al. 2006; Li et al. 2006; Treydte et al. 2006). Tree-ring based streamflow reconstructions have been developed for many areas (e.g. Schulman 
1945; Cook and Jacoby 1983; Cleaveland and Stahle 1989; Cleaveland 2000; Case and McDonald 2003; Gedalof et al. 2004; Woodhouse and Lukas 2006), but few streamflow reconstructions are available for central Asia (Pederson et al. 2001) and the Tien Shan range (Li and Yuan 1996; Li et al. 1994, 1997; Yuan et al. 1996, 2001).

The Manasi River has the largest streamflow among rivers on the northern slope of the Tien Shan mountain range in northwestern China and is the major water resource for the Manasi oasis in Xinjiang. This study aims at reconstructing decadal- to centennial-scale streamflow variability for the Manasi River. For this purpose, we collected Tien Shan spruce tree-ring samples at eight sites in the mountains surrounding the Manasi River basin.

\section{MATERIAL AND METHODS}

\section{Study Area}

The Manasi River headwaters are located on the Yilianhabierga Mountain on the north slope of the Tien Shan mountain range. After collecting 10 tributaries such as the Qingshui River, the Manasi River flows out of the valley and crosses the pediment at the Kensiwate hydrological station (Fig. 1). The catchment of the Manasi Basin up to the Kensiwate hydrological station is $5211 \mathrm{~km}^{2}$. Elevations in the watershed range from 940 to $5289 \mathrm{~m}$. Thirty-eight percent of the basin is situated at elevations above $3600 \mathrm{~m}$, which are perennially snow-covered. The runoff-source area below the snow line, at elevations of 1500 to $3600 \mathrm{~m}$, is well vegetated and has ample precipitation. Tien Shan spruce forests form an important zonal vegetation type in Northwest China (Wang et al. 2004) and are distributed between 1800-2600 $\mathrm{m}$ in the Manasi River Basin.

\section{Tree-Ring Data}

Core samples of the endemic Tien Shan spruce were collected at eight sites near the upper tree line in the Manasi River Basin (Fig. 1; Table 1). The growing season for Tien Shan spruce in our study area lasts approximately from April until September. The sites were character- ized by steep slopes, shallow soil substrates, and little anthropogenic disturbance. Between 39 and 62 samples were collected per site (Table 2).

All cores were air-dried, mounted, and sanded with increasingly fine grade sandpaper to highlight tree-ring borders (Stokes and Smiley 1996). Ring widths were measured to the nearest $0.001 \mathrm{~mm}$ using a VELMEX measuring system, and standard dendrochronological techniques applied for crossdating and chronology development (Fritts 1976; Cook and Kairiukstis 1990). The quality of measurements and visual crossdating was examined using COFECHA software (Holmes 1983) and crossdated series were standardized using ARSTAN software (Holmes 1992). Standardization was applied to remove age and other non-climatic trends and involved fitting a spline that was two thirds the length of the common period of the tree-ring series. The Expressed Population Signal (EPS; Wigley et al. 1984) was used to assess the loss of common variance over time with decreasing sample size for all chronologies. The chronologies were truncated when EPS dropped below 0.85 .

We used the eight standardized tree-ring chronologies to model water-year streamflow. Standardized chronologies are more appropriate for open-canopy sites (such as our study sites) than prewhitened chronologies (Cook 1985).

\section{Hydrometeorological Data}

We employed water-year (October-September) streamflow data from the Manasi River, gauged at the Kensiwate hydrological station, for tree-ring calibration. These data were provided by the Hydrological and Water Resources Bureau of Xinjiang. As no time series of monthly streamflow data were available, we used annual data for the period 1956-2000. The location and type of gage at the Kensiwate hydrological station have not changed and streamflow data are expected to be homogenous over this period of time. Average water-year streamflow (1956-2000) is $464 \mathrm{~m}^{3} \mathrm{~s}^{-1}$, the majority of which consists of glacier meltwater $(34.9 \%)$ and underground base flow (43.7\%; Xinjiang Water Conservency Agency and Academy 1999) and occurs in Summer (June-August; 


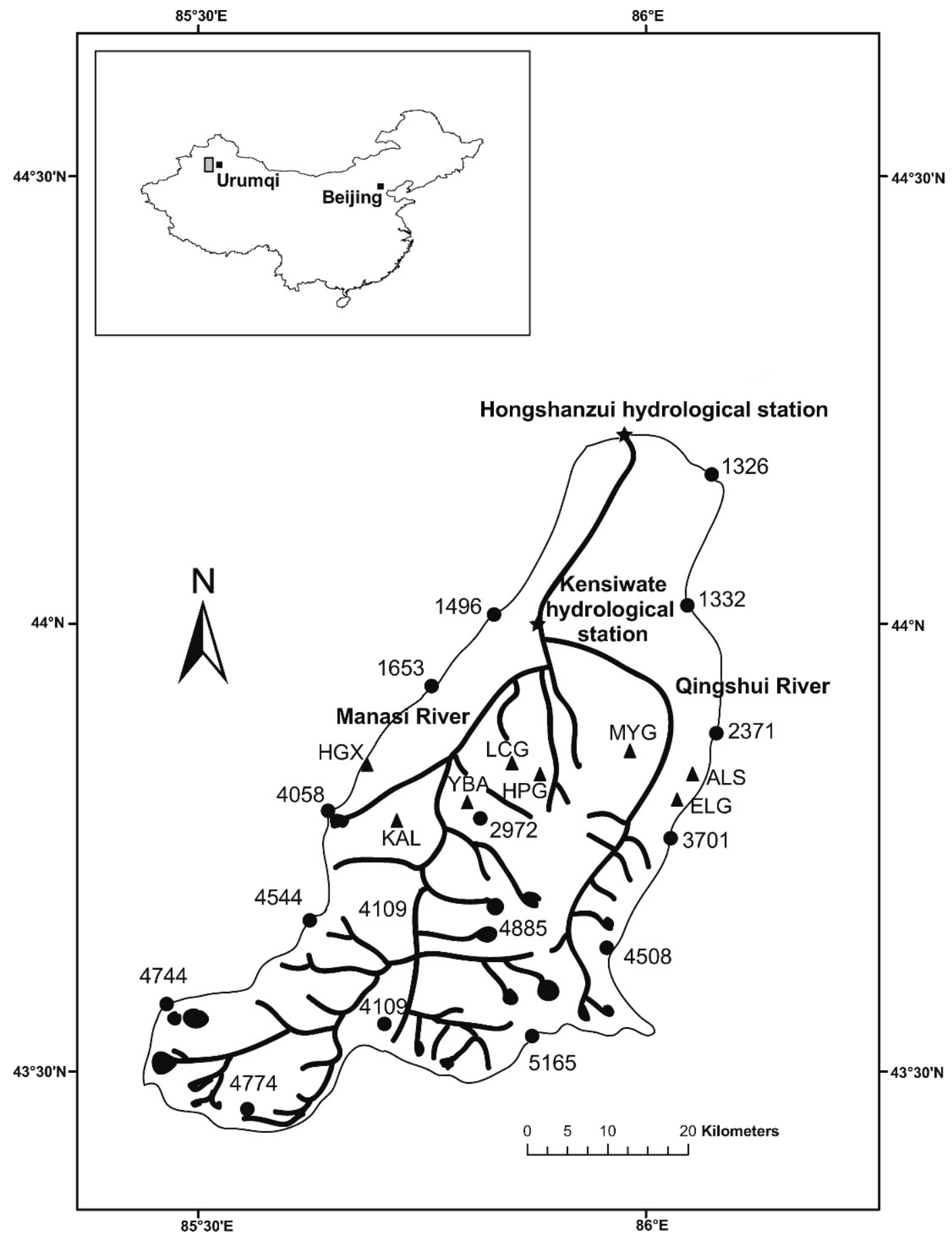

Figure 1. Location of tree-ring sampling sites (triangles) and hydrological stations (stars) in the Manasi River Basin. 
Table 1. Site characteristics for eight tree-ring sampling sites in the Manasi River Basin on the north slope of the Tien Shan mountain range.

\begin{tabular}{|c|c|c|c|c|c|c|}
\hline Site & Abbrev. & Long (E) & Lat $(\mathrm{N})$ & Elev. (m) & Aspect & Slope \\
\hline Hong Valley & HGX & 85.69 & 43.84 & 2425 & $\mathrm{~N}$ & 30.3 \\
\hline Kalasayi & KAL & 85.71 & 43.8 & 2496 & NW & 31.1 \\
\hline Yaba Valley & YBA & 85.8 & 43.8 & 2477 & $\mathrm{E}-\mathrm{S}$ & 29.2 \\
\hline Lucao Valley & LCG & 85.9 & 43.82 & 2473 & NW & 23.3 \\
\hline Heping Valley & HPG & 85.92 & 43.8 & 2512 & NW-NE & 37.9 \\
\hline Meiyao Valley & MYG & 86.03 & 43.81 & 2542 & $\mathrm{~N}-\mathrm{NE}$ & 42.5 \\
\hline Elagayisayi & ELG & 86.04 & 43.79 & 2631 & $\mathrm{NE}-\mathrm{NW}$ & 30.8 \\
\hline Alasan & ALS & 86.14 & 43.8 & 2614 & $\mathrm{NNE}-\mathrm{N}$ & 28.3 \\
\hline
\end{tabular}

Fig. 2). Data for the year 1975 were missing and have been interpolated based on data from the hydrological station Hongshanzui, situated downstream from the Kensiwate hydrological station (Fig. 1). The two time-series were strongly correlated $(\mathrm{r}=0.937, \mathrm{p}<0.001)$ for the period 19561993 (excluding the year 1975). The Manasi River water-year streamflow is strongly autocorrelated at time-lags of one $(r=0.631, p<0.001)$ to three $(\mathrm{r}=0.355, \mathrm{p}<0.05)$ years.

\section{Streamflow Reconstruction}

We applied a transfer function approach to model annual streamflow (Fritts 1976; Cook and Kairiukstis 1990). This approach consists of three phases: calibration, verification, and reconstruction.
Multiple stepwise regression was applied in the calibration phase to develop a linear model. This model allows estimation of annual streamflow from a set of potential tree-ring predictors. Our set of potential tree-ring predictors included the eight spline detrended standard chronologies. Several combinations of these data were considered for model development, including lagged treering responses (i.e. tree-ring data of years preceding the year in which streamflow was measured) of one to four years. Precipitation in the Tien Shan mountains can affect river streamflow over the following three to five years, mainly because of local soil interception rates ( $\mathrm{Li}$ et al. 2000).

The full set of common years between the tree-ring data set and the instrumental streamflow

Table 2. Statistical characteristics for eight tree-ring chronologies of the Manasi River Basin on the north slope of the Tien Shan mountain range.

\begin{tabular}{lccccccccc}
\hline $\begin{array}{c}\text { Tree-ring } \\
\text { chronology }\end{array}$ & $\begin{array}{c}\text { No. of } \\
\text { Samples }\end{array}$ & $\begin{array}{c}\text { Chronology } \\
\text { Length }\end{array}$ & $\begin{array}{c}\mathrm{MGR}^{\mathrm{a}} \\
(\mathrm{mm})\end{array}$ & $\mathrm{MSV}^{\mathrm{b}}$ & $\mathrm{SD}^{\mathrm{c}}$ & RBAR $^{\mathrm{d}}$ & PCl $^{\mathrm{e}}(\%)$ & $\mathrm{AR}^{\mathrm{f}}$ & $\mathrm{EPS}^{\mathrm{g}}$ \\
\hline HGX & 51 & $1624-2002$ & 0.47 & 0.15 & 0.21 & 0.29 & 32 & 0.55 & 0.9 \\
KAL & 55 & $1521-2002$ & 0.5 & 0.14 & 0.18 & 0.29 & 32 & 0.46 & 0.91 \\
YBA & 43 & $1629-2002$ & 0.79 & 0.18 & 0.23 & 0.52 & 53 & 0.54 & 0.95 \\
LCG & 62 & $1523-2002$ & 0.55 & 0.14 & 0.19 & 0.38 & 41 & 0.58 & 0.95 \\
HPG & 42 & $1598-2000$ & 0.61 & 0.13 & 0.14 & 0.33 & 36 & 0.33 & 0.91 \\
MYG & 39 & $1684-2000$ & 0.69 & 0.13 & 0.17 & 0.31 & 35 & 0.49 & 0.85 \\
ELG & 49 & $1663-2003$ & 0.59 & 0.16 & 0.19 & 0.36 & 39 & 0.44 & 0.93 \\
ALS & 45 & $1560-2003$ & 0.42 & 0.14 & 0.2 & 0.32 & 35 & 0.61 & 0.9 \\
\hline
\end{tabular}

\footnotetext{
${ }^{a}$ MGR: mean annual growth rate.

${ }^{\mathrm{b}} \mathrm{MSV}$ : mean sensitivity value.

${ }^{\mathrm{S}} \mathrm{SD}$ : standard deviation.

${ }^{\mathrm{d}} \mathrm{RBAR}$ : mean correlation coefficient between all tree-ring series used in a chronology.

${ }^{\mathrm{e}} \mathrm{PC} 1$ : percentage of variance explained by the first Principal Component of the individual series.

${ }^{\mathrm{f}} \mathrm{AR}$ : variance related to autoregression.

${ }^{\mathrm{g}}$ EPS: expressed population signal.
} 


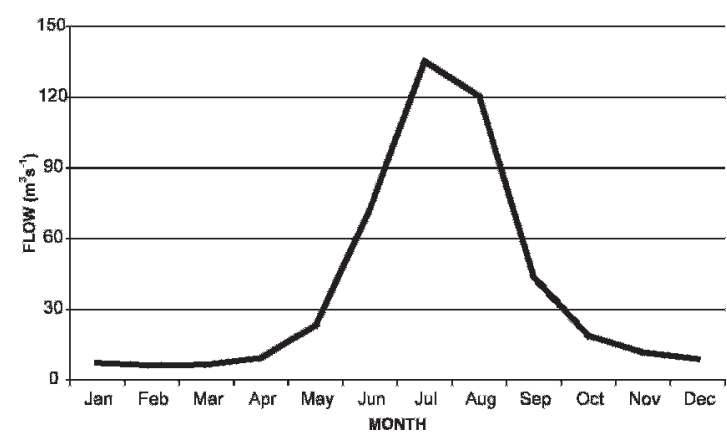

Figure 2. Average (1961-2000) monthly streamflow hydrograph for the Manasi River at the Kensiwate hydrological station.

data (1956-2000) was used as the calibration period. The calibration model was evaluated based on the variance in the instrumental record explained by the model $\left(\mathrm{R}_{\text {cal }}^{2}\right)$. The model was verified using the leave-one-out cross validation method (Michaelsen 1987; Woodhouse and Lukas 2006). This method calibrates a model based on all predictor values but one, which is then estimated. It is an iterative process, in which all predictor values are left out of the calibration period and estimated. Verification tests included the reduction of error (RE) and sign test (Fritts 1976; Cook et al. 1994).

In a final step, the developed model was applied to the full length of the tree-ring data to generate a preliminary streamflow reconstruction.

\section{RESULTS}

\section{Tree-Ring Chronology Development}

We developed eight ring-width chronologies for the Manasi River Basin (Fig. 3). The chronologies show comparable mean annual growth rates (0.42-0.79 mm; Table 2), mean sensitivity values (0.13-0.18), and standard deviations (0.14-0.23). The mean correlation coefficients between all treering series used in the chronologies (RBAR) and the percentages of variance explained by the first Principal Component of the individual series (PC1) were more variable between sites. Values were relatively high for all sites, however, and, together with the high EPS values, suggest that distinct environmental signals are contained in the tree-ring data (Fritts and Schatz 1975). The presence of a common climatic signal in the eight chronologies is confirmed by the strong positive correlations between the chronologies ( $\mathrm{r}=0.5$ to $\mathrm{r}=0.81, \mathrm{p}<0.001)$ over the common period (1684-2000). The high values of the first-order autocorrelation (AR; 0.33-0.61) are an indication of the low-frequency variance contained in the series, and could be explained by climate or by the lagged response of tree physiology (e.g. multiannual needle retention).

\section{Streamflow Model}

All tree-ring chronologies were positively correlated with water-year streamflow (Table 3). The climatic conditions associated with high streamflow thus appear to also be associated with wide tree rings. Correlations were generally strongest for the chronologies preceding the streamflow time series by three to four years. This time lag can be explained by slow soil interception rates in mountain areas (Li et al. 2000).

We averaged the three chronologies that correlated best with streamflow (YBA, HPG, and ALS) into a single regional chronology (YHA) to model water-year streamflow. The strong correlations between the three chronologies $(\mathrm{r}=0.56$ to $\mathrm{r}=0.72 ; 1956-2000)$ support the rationale of mathematically averaging these timeseries. The average time series shows strong positive correlations with water-year streamflow at all time lags (Table 3). Adding a fourth chronology to the average did not improve correlations.

We developed a multivariate transfer function to estimate water-year streamflow for the calibration period (1956-2000) based on the regional chronology at different time-lags. The following transfer function explained $51 \%$ of the interannual variation in streamflow (Fig. 4):

$$
\mathrm{W}_{\mathrm{t}}=29.8+5.32 \mathrm{YHA}_{\mathrm{t}-3}^{5}+2.93 \mathrm{YHA}_{\mathrm{t}}^{5}
$$

where $\mathrm{W}(\mathrm{t})$ is the water-year streamflow at Kensiwate hydrological station in year $t$, and $\mathrm{YHA}_{\mathrm{t}}$ and $\mathrm{YHA}_{\mathrm{t}-3}$ are the regional tree-ring chronology indices in the concurrent year and preceding the streamflow year by three years, 

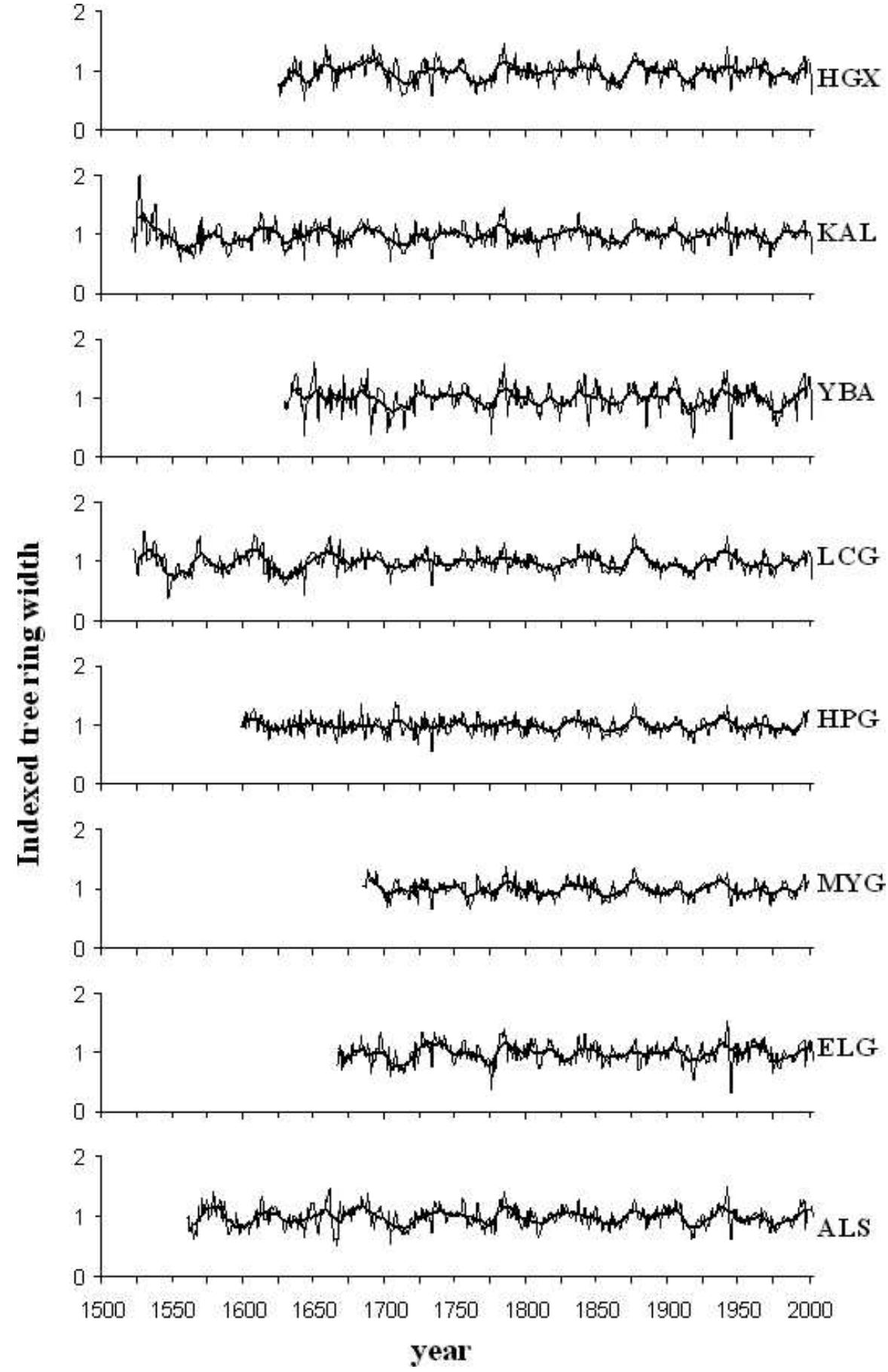

Figure 3. Eight standardized ring-width chronologies for the Manasi River basin. Centered 11-year moving averages (bold lines) are superimposed on the ring-width series. 
Table 3. Pearson correlation coefficients between eight tree-ring chronologies and the average of three chronologies (YHA), and water-year streamflow for the Manasi River (1956-2000). Correlations were calculated for the concurrent year $(t)$ and for the treering data preceding the streamflow data up to 4 years ( $t-1$ to t-4). Significant correlations are indicated ( $<<0.05^{*}$ and $\mathrm{p}<0.01^{* *}$ ).

\begin{tabular}{llllll}
\hline & $\mathrm{t}$ & $\mathrm{t}-1$ & $\mathrm{t}-2$ & $\mathrm{t}-3$ & $\mathrm{t}-4$ \\
\hline HGX & $0.3^{*}$ & $0.3^{*}$ & 0.29 & $0.41^{* *}$ & $0.32^{*}$ \\
KAL & 0.06 & 0.1 & 0.24 & $0.39^{* *}$ & $0.35^{*}$ \\
YBA & $0.38^{*}$ & 0.24 & $0.34^{*}$ & $0.44^{* *}$ & $0.47^{* *}$ \\
LCG & 0.26 & 0.24 & 0.25 & $0.32^{*}$ & 0.22 \\
HPG & $0.48^{* *}$ & $0.41^{* *}$ & $0.4^{* *}$ & $0.41^{* *}$ & 0.2 \\
MYG & 0.27 & 0.24 & $0.36^{*}$ & $0.45^{* *}$ & $0.34^{*}$ \\
ELG & 0.21 & 0.06 & 0.13 & $0.37^{*}$ & $0.47^{* *}$ \\
ALS & 0.28 & 0.18 & $0.3^{*}$ & $0.52^{* *}$ & $0.55^{* *}$ \\
\hline YHA & $0.43^{* *}$ & $0.32^{*}$ & $0.41^{*}$ & $0.51^{* *}$ & $0.52^{* *}$ \\
\hline
\end{tabular}

respectively. Raising the tree-ring predictors in the model to the $5^{\text {th }}$ power was necessary to fit the different characteristics of tree-ring and streamflow data.

The statistical verification results for the transfer function model are shown in Table 4. The average variance explained by the leave-oneout validation models $\left(\mathrm{R}_{\mathrm{a}, \text { ver }}^{2}\right)$ is high and the same as the variance explained by the calibration model $\left(\mathrm{R}_{\mathrm{a}, \mathrm{cal}}^{2}\right)$. The high $\mathrm{RE}$ value and the significant ( $\mathrm{p}$ $<0.05)$ result of the sign test indicate that the transfer function model that we developed is a stable and reliable estimation of water year streamflow.

\section{Streamflow Reconstruction}

On the basis of the multivariate transfer model, we developed a preliminary water-year streamflow reconstruction of the Manasi River for the period 1629-2000 (Fig. 5). The statistical parameters of the gaged streamflow data are

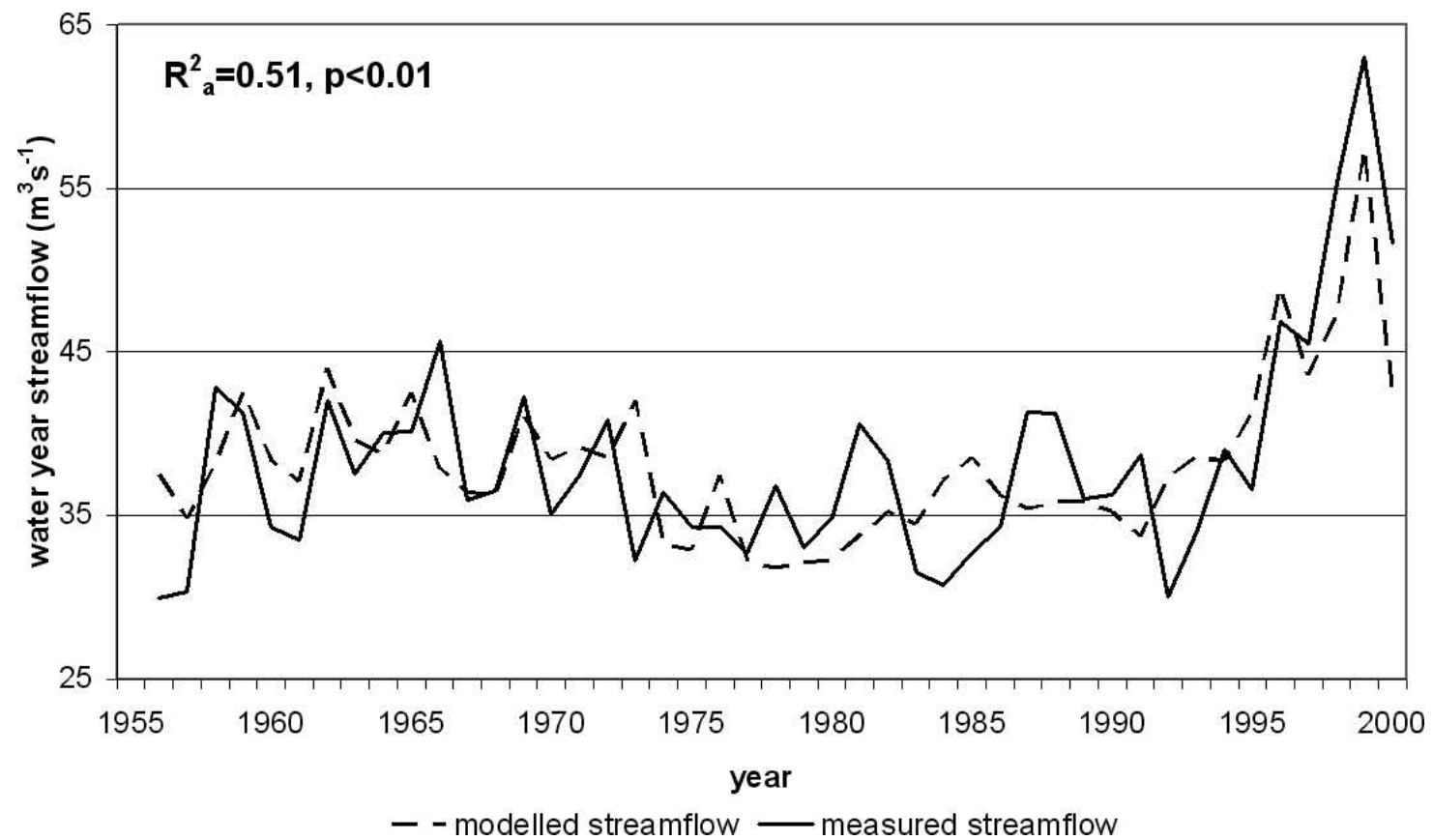

Figure 4. Measured versus modeled water year streamflow for the Manasi River over the calibration period (1956-2000). 
Table 4. Transfer function model calibration and verification statistics.

\begin{tabular}{lc}
\hline $\mathrm{R}_{\mathrm{a}, \text { cal }}^{2}$ & 0.51 \\
$\mathrm{R}_{\mathrm{a}, \text { ver }}$ & 0.51 \\
$\mathrm{RE}$ & 0.44 \\
Sign Test & $30 / 45$ \\
\hline
\end{tabular}

reasonably well reproduced by the reconstructed streamflow data (Table 5). The average and median reconstructed water year streamflow are slightly higher than the average and median gaged water year streamflow. This discrepancy can be explained by the fifth power of the tree-ring chronologies in the model (equation 1). Raising the chronologies to this power enlarges the positive deviations from the mean and diminishes the negative deviations. Minimum values accordingly are higher for the reconstructed streamflow than for the gaged streamflow (Table 5). The lower variance found for reconstructed streamflow compared to gaged streamflow reflects specific limitations of tree-ring reconstructions, which generally are conservative estimations of the observed values (Woodhouse 2003).
We used the reconstruction to evaluate streamflow over the period 1629-2000. For this purpose, we calculated the 10 most extreme, nonoverlapping wet and dry 5-year intervals (Pederson et al. 2001; Table 6). The driest period was 1917-1921 and the wettest 1941-1945. The longest extended dry period lasted 14 years (1911-1924), equally long as the two longest extended wet periods (1782-1795 and 1936-1949).

\section{DISCUSSION}

We reconstructed water-year streamflow for the Manasi River in the northern Tien Shan Mountains in northwestern China for the period 1629-2000 (Fig. 5). We developed eight Tien Shan spruce tree-ring chronologies for the Manasi River Basin for this purpose (Fig. 3).

Previous studies have shown that Tien Shan spruce is a valuable species for tree-ring analysis (Wang et al. 2004, 2005; Li et al. 2006). Precipitation is the principal limiting factor for Tien Shan spruce growth in the Tien Shan Mountains, even at high-elevation tree-line sites (Wang et al.

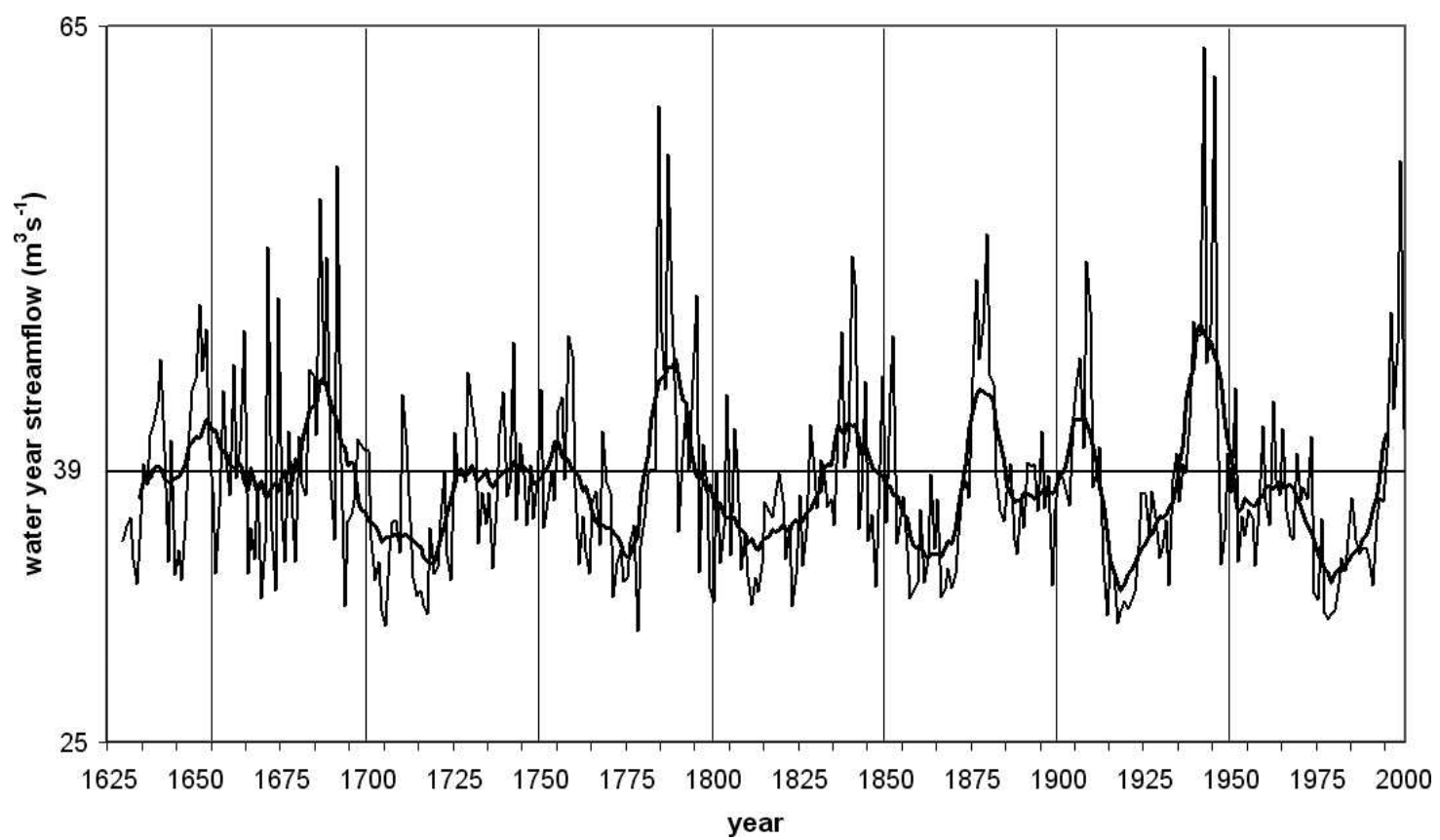

Figure 5. Reconstructed water-year streamflow $\left(\mathrm{m}^{3} / \mathrm{s}\right)$ plotted with 11 -year running average (bold line). The horizontal line indicates the $1629-2000$ reconstructed mean $\left(39.4 \mathrm{~m}^{3} / \mathrm{s}\right)$. 
Table 5. Statistical parameters of gaged and reconstructed water-year streamflow of the Manasi River on the north slope of the Tien Shan Mountains.

\begin{tabular}{lccc}
\hline \multicolumn{1}{c}{$\begin{array}{c}\text { Statistical } \\
\text { Parameter }\end{array}$} & Gaged & Reconstructed & Reconstructed \\
1956-2000 & 1956-2000 & 1629-2000 \\
\hline Mean & 38.3 & 38.3 & 39.4 \\
Median & 36.6 & 37.5 & 38.5 \\
Standard deviation & 6.6 & 4.9 & 5.3 \\
Maximum & 63 & 57.5 & 63.8 \\
Minimum & 29.9 & 31.8 & 31.2 \\
Range & 33.1 & 25.7 & 32.6 \\
\hline
\end{tabular}

2005). Tien Shan spruce forests are widely distributed across northwestern China, allowing the potential development of a dense network of tree-ring chronologies from this area.

The eight tree-ring chronologies showed strongly similar interannual variability, indicating the dominating influence of a common hydroclimatic signal. This hydroclimatic forcing driving interannual variations in tree growth affects streamflow variations in the concurrent year, as well as on a three- to four-year time-lag (Table 3). Considering the high proportion of Manasi River water-year streamflow that consists of underground base flow, interception of precipitation by the soil is probably the cause for this multi-year lag. Soil interception of precipitation is the main cause for lagged hydroclimatic effects on river streamflow in mountain areas (Stockton 1975). In addition to this, hydroclimatic factors have a multi-year effect on tree growth, particularly in (semi-)arid regions such as our study area (Fritts 1974). The lagged effect of precipitation on both streamflow and tree growth was reflected by including lagged predictors in and thus attributing an autoregressive structure to the model.

The non-linear model we developed to estimate water year streamflow was based on the average of three of the eight developed tree-ring chronologies. The calibration and verification statistics for the period 1956-2000 suggest that the model is a stable and reliable estimation of water-year streamflow. The variance explained by the model was increased dramatically by raising the tree-ring chronologies to the $5^{\text {th }}$ power. Although the regional tree-ring chronology shows an increase since 1995, this increase in tree growth
Table 6. Ten most extreme, non-overlapping wet and dry 5-year intervals for the Manasi River streamflow reconstruction.

\begin{tabular}{rcc}
\hline Rank & Dry & Wet \\
\hline 1 & $1917-1921$ & $1941-1945$ \\
2 & $1977-1981$ & $1784-1788$ \\
3 & $1913-1917$ & $1876-1880$ \\
4 & $1713-1717$ & $1684-1688$ \\
5 & $1702-1706$ & $1996-2000$ \\
6 & $1866-1870$ & $1905-1909$ \\
7 & $1810-1814$ & $1649-1653$ \\
8 & $1857-1861$ & $1837-1841$ \\
9 & $1771-1775$ & $1937-1941$ \\
10 & $1775-1779$ & $1688-1692$ \\
\hline
\end{tabular}

is not as explicit as the increase in streamflow for this time period. Non-linear relationships between tree growth and streamflow can be explained by the fact that tree growth can not increase at the same rate as precipitation (and resulting streamflow) when precipitation levels are very high, because of growth restraints such as nutrient supplies (Fritts 1976). Raising the tree-ring chronology indices to the $5^{\text {th }}$ power allows for a more accurate modeling of this explicit increase in streamflow over the last five years of the calibration period (Fig. 4).

The variance in gaged streamflow explained by the tree-ring model is further limited by the lack of monthly streamflow data. Monthly data would allow us to select the months/season in which the hydroclimatic conditions driving tree growth have the strongest influence on streamflow. Streamflow in the Tien Shan region is mainly driven by precipitation and has components of both rainfall and snowmelt. Hydrographs of high mountain rivers in the northern Tien Shan with glaciation areas between 30 and $40 \%$, typically show two floods. The melting of seasonal snow cover on the glacial tongue and on non-glacial surfaces causes a spring flood, followed by a second flood in Summer, consisting mainly of glacier meltwater (Aizen et al. 1996). The second flood is usually larger than the first. Direct runoff from rain can only be observed on hydrographs when storm precipitation with an intensity larger than $20 \mathrm{~mm}$ day $^{-1}$ occurs (Aizen et al. 1996). The contribution of precipitation variability (driving tree growth 
variability) to streamflow potentially has a strongly seasonal character, despite the absence of a spring flood in the Manasi River hydrograph (Fig. 2).

The reconstruction based on the proposed model is preliminary based on various factors. The model is multivariate in nature, which increases the chances of overfitting. Furthermore, the non-linearity of the model, necessary to fit proxy and target characteristics, and the explicit time-lag between tree growth and streamflow require further investigation. The efficacy of the model could further be enhanced by calibrating it with monthly or seasonal streamflow data.

A multi-century reconstruction of the Manasi River streamflow could provide a longer context for evaluating the recent increasing trends. Streamflow levels since 1995 have been greatly exceeding previous levels on record since 1955, but our preliminary reconstruction suggests that 19962000 is only the $5^{\text {th }}$ wettest period since 1629 (Table 6). A longer-term reconstruction also allows for the detection of sustained periods of drought or flood, which are particularly challenging for managing water systems. Sustained wet and dry periods of the Manasi River lasted up to 14 years according to our reconstruction. The most extensive wet periods in our study correspond to periods of maximum spring precipitation days in the middle Tien Shan Mountains (1940s; Yuan et al. 2003) and with a period of extended increased streamflow of the Selenge River in westcentral Mongolia (1780s; Davi et al. 2006). The longest extended dry period (1911-1924) corresponds to drought records for Mongolia, derived from tree-ring data (Pederson et al. 2001; Davi et al. 2006) and from historical documents (Mijiddorj and Namhay 1993 (in Pederson et al. 2001)). Various other drought periods in our reconstruction (Table 6) also appear in tree-ring reconstructions for the Urumqi River drainage in the Tien Shan Mountains (1710s; Yuan et al. 2003) and in Mongolia (1771-1775 and 1977-1981; Pederson et al. 2001). The two extended drought periods in the 1800s (approx. 1800-1830 and 1850-1875; Fig. 5) in particular were widespread and were found in various records for Central Asia (Pederson et al. 2001; Yuan et al. 2001; Davi et al. 2006).
The tree-ring based streamflow reconstruction we present in this paper illustrates the potential and the usefulness of tree-ring data as proxy hydroclimatic data in the Tien Shan Mountains in northwestern China. Given the sensitivity of Tien Shan spruce tree growth in this region to the hydroclimatic factors influencing streamflow, there is a potential to develop regionally explicit streamflow reconstructions. These allow for long-term, reliable contexts for water management and the development of water policies and infrastructure.

\section{ACKNOWLEDGMENTS}

We thank Liu Bing, Zhu Yunchuan, and Guo Jianguo (Xinjiang Forest Department) for their support. Helpful comments by Malcolm K. Cleaveland, Jan Esper, and two anonymous reviewers have improved this manuscript substantially. This work was supported by the National Natural Science Foundation (Grant No. 40265002 and 40475041).

\section{REFERENCES CITED}

Aizen, V. B., E. M. Aizen, and J. M. Melack, 1996. Precipitation, melt and runoff in the northern Tien Shan. Journal of Hydrology 186:229-251.

Aizen, V. B., E. M. Aizen, J. M. Melack, and J. Dozier, 1997. Climatic and hydrologic changes in the Tien Shan, Central Asia. Journal of Climate 10:1393-1404.

Aizen, E. M., V. B. Aizen, J. M. Melack, T. Nakamura, and T. Ohta, 2001. Precipitation and atmospheric circulation patterns at mid-latitudes of Asia. International Journal of Climatology 21:535-556.

Case, R. A., and G. M. McDonald, 2003. Tree ring reconstructions of streamflow for three Canadian rivers. Journal of the American Water Resources Association 38: 703-716.

Cleaveland, M. K., 2000. A 963-year reconstruction of summer (JJA) streamflow in the White River, Arkansas, USA, from tree-rings. The Holocene 10:33-41.

Cleaveland, M. K., and D. W. Stahle, 1989. Tree ring analysis of surplus and deficit runoff in the White River, Arkansas. Water Resources Research 25:1391-1401.

Cook, E. R., 1985. A Time Series Analysis Approach to TreeRing Standardization. Ph.D. dissertation, University of Arizona, Tucson.

Cook, E. R., K. R. Briffa, and P. D. Jones, 1994. Spatial regression methods in dendroclimatology: a review and 
comparison of two techniques. International Journal of Climatology 14:379-402.

Cook, E. R., and G. C. Jacoby, 1983. Potomac River streamflow since 1730 as reconstructed by tree rings. Journal of Applied Meteorology 22:1659-1672.

Cook, E. R., and L. Kairiukstis, 1990. Methods of Dendrochronology: Applications in the Environmental Sciences. Kluwer Academic Publishers, Dordrecht, The Netherlands.

Davi, N. K., G. C. Jacoby, A. E. Curtis, and N. Baatarbileg, 2006. Extension of drought records for Central Asia using tree rings: west-Central Mongolia. Journal of Climate 19: 288-299.

Esper, J., D. C. Frank, R. J. S. Wilson, U. Büntgen, and K. Treydte, 2007. Uniform growth trends among central Asian low and high elevation juniper tree sites. Trees 21:141-150.

Esper, J., F. H. Schweingruber, and M. Winiger, 2002. 1,300 years of climate history for Western Central Asia inferred from tree-rings. The Holocene 12:267-277.

Esper, J., S. G. Shiyatov, V. S. Mazepa, R. J. S. Wilson, D. A. Graybill, and G. Funkhouser, 2003. Temperature-sensitive Tien Shan tree ring chronologies show multi-centennial growth trends. Climate Dynamics 8:699-706.

Fritts, H. C., 1974. Relationships of ring-widths in arid site conifers to variations in monthly temperature and precipitation. Ecological Monographs 44:411-440.

Fritts, H. C., 1976. Tree Rings and Climate. Academic Press, New York.

Fritts, H. C., and D. J. Schatz, 1975. Selecting and characterizing tree-ring chronologies for dendroclimatic analysis. TreeRing Bulletin 35:31-46.

Gao, X. Z. Zao, and Y. Ding, 2001. Climate change due to greenhouse effect in China as simulated by a regional climate model. Advances in Atmospheric Sciences 18:53-66.

Gedalof, Z., D. L. Peterson, and N. J. Mantua, 2004. Columbia River flow and drought since 1750. Journal of the American Water Resources Association 40:1579-1592.

Gong, Y., Y. J. Yuan, and Q. He, 2003. Influence of climate warming and human activity on relationship between precipitation and runoff for a middle-small river of northern Xinjiang. Journal of Desert Research 23:569-572 [in Chinese.]

Hansen, J., I. Fung, A. Lacis, D. Rind, S. Lebedeff, R. Ruedy, G. Russell, and P. Stone, 1988. Global climate changes as forecast by Goddard Institute for Space Studies threedimensional model. Journal of Geophysical Research 93(D8):9341-9364.

He, Q., Y. J. Yuan, W. S. Wei, and Y. Gong, 2003. Probe into response of surface water resources to climate change in Xinjiang. Journal of Desert Research 23:493-496 [in Chinese.]

Holmes, R. L., 1983. Computer-assisted quality control in treering dating and measurement. Tree-Ring Bulletin 44:69-75.

Holmes, R. L., 1992. Program ARSTAN (Version B-1992). Laboratory of Tree-Ring Research, University of Arizona, Tucson.

Hu, Z. Z., S. Yang, and R. G. Wu, 2003. Long-term climate variations in China and global warming signals. Journal of Geophysical Research 108(D19), doi: 10.1029/2003JD003651.

Jiang, F., C. Zhu, G. Mu, and R. Hu, 2002. Recent magnification of flood and drought calamities in Xinjiang: analysis of anthropogenic effects. Acta Geographica Sinica 57:57-66 [in Chinese.]

Jiang, F., C. Zhu, G. Mu, R. Hu, and Q. Meng, 2005. Magnification of flood disasters and its relation to regional precipitation and local human activities since the 1980s in Xinjiang, northwestern China. Natural Hazards 36:307330 .

Li, J., and Y. Yuan, 1996. Tree ring reconstruction of the annual runoff field in Yili region. Hydrology 1:30-35 [in Chinese.]

Li, J., X. Gou, E. R. Cook, and F. Chen, 2006. Tree-ring based drought reconstruction for the central Tien Shan area in northwest China. Geophysical Research Letters 33:L07715, doi: 10.1029/2006 GL02583.

Li, J., Y. Yuan, H. Ma, Z. Zhao, and J. Wang, 1994. Reconstruction of the historical runoff depth field in the Yili area, Xinjiang. Journal of Natural Resources 9:67-76 [in Chinese.]

Li, J., Y. Yuan, and X. You, 1997. 360 years' runoff reconstruction in the Urumqi River basin using tree rings. Quaternary Sciences 17:131-138 [in Chinese.]

Li, J., Y. Yuan, and X. You, 2000. Dendrohydrology Research and Its Application. Science Press, Beijing [in Chinese.]

Mao, W. Y., C. Chen, J. J. Duan, H. C. Su, S. F. Wang, J. Wang, and F. Y. Ge, 2004. Streamflow regime of four source streams and mainstream of Tarim River, Xinjiang, in 2000. Journal of Glaciology and Geocryology 26:488-495 [in Chinese.]

Mao, W. Y., H. D. Li, J. Jiang, S. Chen, B. G. Sun, and J. Huang, 2005. Flood patterns and $500 \mathrm{hPa}$ circulation patterns of flooding formation in Aksu River Basin, Xinjiang. Journal of Glaciology and Geocryology 27:574-581 [in Chinese.]

Michaelsen, J., 1987. Cross-validation in statistical climate forecast models. Journal of Climate and Applied Meteorology 26:1589-1600.

Mijjidorj, R., and A. Namhay, 1993. On drought and unfavorable winter conditions recurrence in Mongolia. Transactions of the HMRI 11:118-131 [in Russian.]

Pederson, N., G. C. Jacoby, R. D. D’Arrigo, E. R. Cook, B. M. Buckley, C. Dugarjav, and R. Mijiddorj, 2001. Hydrometeorological reconstructions for northeastern Mongolia derived from tree rings: 1651-1995. Journal of Climate 14: 872-881.

Schulman, E., 1945. Tree-rings and runoff in the South Platte River Basin. Tree-Ring Bulletin 11:18-24.

Shi, Y., Y. Shen, E. Kang, D. Li, Y. Ding, G. Zhang, and R. $\mathrm{Hu}, 2007$. Recent and future climate change in northwest China. Climatic Change 80:379-393.

Stockton, C. W., 1975. Long-Term Streamflow Records Reconstructed from Tree Rings. Papers of the Laboratory of TreeRing Research, Vol. 5. University of Arizona Press, Tucson.

Stokes, M. A., and T. L. Smiley, 1996. An Introduction to TreeRing Dating. University of Arizona Press, Tucson.

Su, L., Y. D. Song, and Z. Y. Zhang, 2005. Response of the climate and ecological environment in the northern slope of the Tianshan Mountains to global warming during the recent 40 years. Arid Land Geography 28:342-346 [in Chinese.] 
Tian, L., T. Yao, Z. Li, K. MacClune, G. Wu, B. Xu, Y. Li, A. $\mathrm{Lu}$, and $\mathrm{Y}$. Shen, 2006. Recent rapid warming trend revealed from the isotopic record in Muztagata ice core, eastern Pamirs. Journal of Geophysical Research 111:D13103, doi: 10.1029/2005JD006249.

Treydte, K., G. H. Schleser, G. Helle, D. C. Frank, M. Winiger, G. H. Haug, and J. Esper, 2006. Millennium-long precipitation record from tree-ring oxygen isotopes in northern Pakistan. Nature 440:1179-1182.

Wang, T., Y. Liang, H. Ren, D. Yu, J. Ni, and K. Ma, 2004. Age structure of Picea schrenkiana forest along an altitudinal gradient in the central Tianshan Mountains, northwestern China. Forest Ecology and Management 196:267-274.

Wang, T., H. Ren, and K. Ma, 2005. Climatic signals in tree rings of Picea schrenkiana along an altitudinal gradient in the central Tianshan Mountains, northwestern China. Trees 19: 735-741.

Wigley, T. M., K. R. Briffa, and P. D. Jones, 1984. On the average value of correlated time series, with applications in dendroclimatology and hydrometeorology. Journal of Climate and Applied Meteorology 23:201-213.

Woodhouse, C. A., 2003. A 431-yr reconstruction of western Colorado snowpack from tree rings. Journal of Climate 16: $1551-1561$

Woodhouse, C. A., and J. J. Lukas, 2006. Multi-century treering reconstructions of Colorado streamflow for water resource planning. Climatic Change 78:293-315; doi: 10.10070s10584-006-9055-0.

Xie, C. W., Y. J. Ding, S. Y. Liu, and H. D. Han, 2004. Analysis on the glacial hydrological features of the glaciers on the south slope of Mt. Tuomuer and the effects on runoff. Arid Land Geography 27:570-575 [in Chinese.]

Xinjiang Water Conservency Agency and Academy, 1999. Hydrology and water resource of Rivers in Xinjiang. Press of Science and Sanitation of Xinjiang, Urumqi.

Ye, B., D. Yongjian, E. Kang, G. Li, and T. Han, 1999. Response of the snowmelt, and glacier runoff to the climate warming-up in the last 40 years in Xinjiang Autonomous Region, China. Science in China Series D-Earth Sciences 42: 44-51 [in Chinese.]

Ye, B., D. Yang, K. Jiao, T. Han, Z. Jin, H. Yang, and Z. Li, 2005. The Urumqi River source Glacier No. 1, Tianshan, China: changes over the past 45 years. Geophysical Research Letters 32:L21504, doi:10.1029/2005GLO24178.

Yuan, Y., J. Li, R. Hu, C. Liu, K. Jiao, and Z. Li, 2001. Reconstruction of precipitation in the recent $350 \mathrm{a}$ from tree rings in the middle Tianshan mountains. Journal of Glaciology and Geocryology 23:34 40 [in Chinese.]

Yuan, Y., X. Sang, and S. Wu, 1996. The variation features in 250 years and trend prediction in the future of the surface water resource of north Xinjiang. Journal of Natural Resources 11:113-119 [in Chinese.]

Yuan, Y., L. Jin, X. Shao, Q. He, Z. Li, and J. Li, 2003. Variations of the spring precipitation day numbers reconstructed from tree rings in the Urumqi River drainage, Tianshan Mountains, over the last 370 years. Chinese Science Bulletin 48:1507-1510 [in Chinese.]

Received 1 September 2006; Accepted 19 June 2007. 